\title{
Traditional medicines and species extinction: another side to forensic wildlife investigation
}

\author{
Roger W. Byard ${ }^{1}$
}

Accepted: 4 January 2016/Published online: 22 January 2016

(C) Springer Science+Business Media New York 2016

Forensic wildlife investigation is a growing field with significant responsibility for the identification and tracking of illegal trade in endangered and threatened species. Wildlife crime has been estimated to cost between US $\$ 10$ to 20 billion per year globally [1]. While much of the crime involves the illegal collection of uncommon species, or the use of rare materials such as ivory and rhinoceros horn for decorative purposes, one area that is sometimes overlooked is that of traditional medicines [2]. This was exemplified recently when a study dealing with the adulteration of traditional Chinese herbal medicines revealed that a preparation recently bought over the counter in Adelaide, Australia contained the DNA from snow leopard (Panthera uncia), and possibly tiger (Panthera tigris), both of which are listed within the Convention on the International Trade in Endangered Species of flora and fauna (CITES) Appendix I [3]. Clearly any controls on the importation and sale of this preparation had failed. It is also unclear what steps have been taken by authorities to deal with this situation. In 2007 of the approximately 33,600 species protected by CITES, 800 were listed as threatened by extinction and so were under wildlife trade bans [4]. Significantly, it is not only animal species that are endangered, as overharvesting of medicinal plants has also contributed substantial threats to their survival $[5,6]$.

While inadvertent contamination with animal DNA is the most plausible explanation for the detection of dog, cow, goat, sheep, cat, and rat in traditional preparations, it

Roger W. Byard

roger.byard@sa.gov.au

1 School of Medicine, The University of Adelaide, Level 3 Medical School North Building, Frome Road, Adelaide, SA 5005, Australia seems unlikely that an animal as rare as a snow leopard would be included accidentally. The same would apply to pit vipers and frogs which are most likely to have been deliberately added as a primary ingredient $[3,7]$. Undeclared animal ingredients may result in lethal outcomes, particularly if the preparation is taken by an alternate route. This was demonstrated in the case of a 24-year-old male who died suddenly following the intravenous injection of what was thought to be "ecstasy" (MDMA). It transpired that he had injected the traditional Chinese herbal product Chan $S u$ that contains bufotenine, a tryptamine derivative alkaloid found in the secretions of various toads [8].

Traditional Chinese medicine has been called a "significant driver" in the illicit global wildlife trade, with rhinoceros horn used to cure disorders ranging from cerebral hemorrhage to AIDS selling for as much as US\$50,000 per kilogram [9]. Other targeted animals include tigers and mole rats (powdered bones used to treat arthritis/rheumatism), freshwater turtles (shell extracts used to treat cancer), and pangolins (scales used to improve circulation and cure skin disease) $[9,10]$. It has been estimated that $13 \%$ of traditional Chinese medicines contain animal derivatives, despite legislation that has been enacted banning medicines containing rhinoceros horn and tiger bones. Legislation in the United Kingdom specifies that herbal medicines must contain only plant materials [11].

The World Health organization has suggested that $80 \%$ of people in developing countries rely on traditional medicines [5]; this includes using medicines containing animal products, for example, 23 animal species are found in traditional Sudanese therapies [12]. Dried geckos as aphrodisiacs and monkey skeletons for general pain are prescribed in Vietnam. It has been suggested that the latter, in combination with habitat destruction, may result in the white headed leaf monkey (Trachypithecus leucocephalus) 
becoming extinct in the wild [12]. Reptiles are also used in many countries and communities for therapeutic purposes involving an estimated 165 species belonging to 104 genera, consisting of 60 species of snake, 51 lizards, 43 tortoises and turtles, and 11 crocodilians. Of considerable concern is the fact that just over half $(53 \%)$ of these animals are on lists of endangered species [13]. Importantly, the efficacy of many of these animal products in treating disease has not been established [11].

The conditions under which certain animals used to supply material for traditional Chinese medicines are kept have also been criticized. One the most notorious involves the keeping of Asiatic Black or Moon bears (Ursus thibetanus) in small cages to allow the daily milking of bile through catheters; this is then used in traditional medicines for the treatment of digestive illnesses. The bears are also harvested for their gall bladders (xiong dan) [12, 14]. A paper in 2003 reported that 9000 bears were kept on 167 special farms in China, under conditions which were described as "excessively cruel" [11]. Organizations have been established in a number of countries including Laos to repatriate these bears (Fig. 1).

Another problem with traditional preparations is that it may not be possible to tell what ingredients are actually

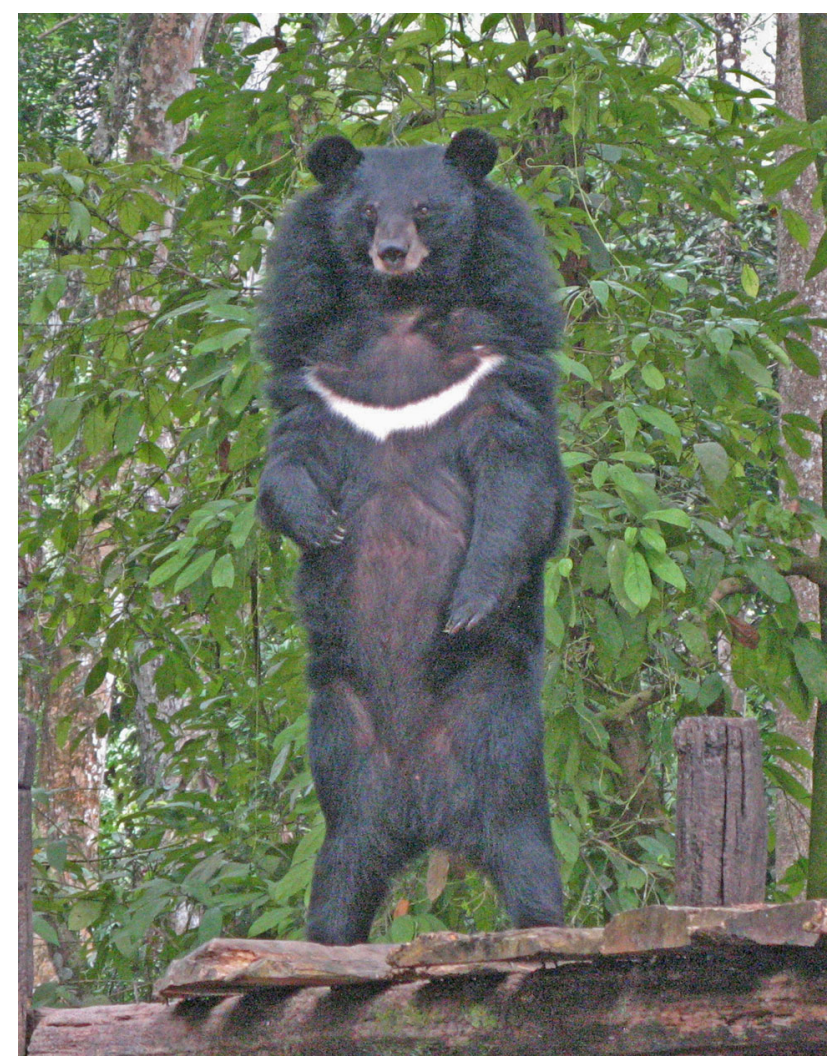

Fig. 1 An asiatic black or moon bear (Ursus thibetanus) used for bile harvesting was freed from captivity and is now resident in the Tat Kuang Si Bear Rescue Center near Luang Prabang in Northern Laos present and in what concentrations. For example, a recent study of products available for purchase in Australia showed that there were significant discrepancies between ingredient concentrations listed on websites compared to their details with the Australian Register of Therapeutic Goods (ARTG) and on product packaging [15]. For this reason sophisticated analyses are sometimes required to ascertain exactly what plant or animal species is present [16].

Questions raised by these issues include what role forensic science may have outside research programs in testing traditional medicines for the presence of endangered species? This then follows on to how the results of these analyses should be conveyed to authorities, and how they will use this information in both Western countries, and in the countries of origin of the preparations, to identify and prosecute offenders and to stop this illegal and very damaging trade. Unfortunately for a number of species it may already be too late.

\section{References}

1. Wilson-Wilde L. Wildlife crime: a global problem. Forensic Sci Med Pathol. 2010;6:221-2.

2. Byard RW. The potential forensic significance of traditional herbal medicines. J Forensic Sci. 2010;55:89-92.

3. Coghlan ML, Maker G, Crighton E, Haile J, Murray DC, White $\mathrm{NE}$, et al. Combined toxicological and genetic auditing of traditional Chinese medicines provides a means of detecting adulterants and improving pharmacovigilance. Sci Rep. 2015;5:17475.

4. Rivalan P, Delmas V, Angulo E, Bull LS, Hall RJ, Courchamp F, et al. Can bans stimulate wildlife trade? Nature. 2007;447:529-30.

5. Kala CP. Status and conservation of rare and endangered medicinal plants in the Indian trans-Himalaya. Biol Conserv. 2000;93:371-9.

6. Sheng-Ji P. Ethnobotanical approaches of traditional medicine studies: some experiences from Asia. Pharmaceut Biol. 2001;39(Suppl):74-9.

7. Coghlan ML, Haile J, Houston J, Murray D, White N, Moolhuijzen $\mathrm{P}$, et al. Deep sequencing of plant and animal DNA contained within traditional Chinese medicines reveals legality issues and health safety concerns. PLoS Genet. 2012;8:e1002657.

8. Kostakis C, Byard RW. Sudden death associated with intravenous injection of toad extract. Forensic Sci Int. 2009;188:e1-5.

9. Graham-Rowe D. Endangered and in demand. Nature. 2011;480:S101-3.

10. Ellis R. Tiger bone and rhino horn: the destruction of wildlife for traditional Chinese medicine. London: Island Press; 2005.

11. Still J. Use of animal products in traditional Chinese medicine: environmental impact and health hazards. Comp Ther Med. 2003;11:118-22.

12. Costa-Neto EM. Animal-based medicines: biological prospection and the sustainable use of zootherapeutic resources. Anais Academ Bras Cien. 2005;77:33-43.

13. Alves RRN, Viera WLS, Santana GG. Reptiles used in traditional folk medicine: conservation implications. Biodivers Conserv. 2008;17:2037-49. 
14. Espinoza EO, Shafer JA, Hagey LR. International trade in bear gall bladders: forensic source inference. J Forensic Sci. 1993;38:1363-71.

15. Blacksell L, Byard RW, Musgrave IF. Forensic problems with the composition and content of herbal medicines. J Forensic Leg Med. 2014;23:19-21.
16. Byard RW, Musgrave I, Hoban C, Bunce M. DNA sequencing and metabolomics - new approaches to the forensic assessment of herbal therapeutic agents. Forensic Sci Med Pathol. 2015;11:1-2. 